\title{
Growth of Phalaenopsis Plants in Five Different Potting Media
}

\author{
Seung Jae Hwang1,2 and Byoung Ryong Jeong ${ }^{1,2,3 *}$ \\ ${ }^{1}$ Division of Applied Life Science, Graduate School, Gyeongsang National University, Jinju 660-701, South Korea \\ ${ }^{2}$ Research Institute of Life Science, Gyeongsang National University, Jinju 660-701, South Korea \\ ${ }^{3}$ Research Institute Agriculture and Life Science, Gyeongsang National University, Jinju 660-701, South Korea
}

To clarify suitable media for the mass production of phalaenopsis orchids, five potting media, New Zealand sphagnum moss (SM, as the control), coir mixes (CM), CM partially mixed with SM, granular rockwool mixes and perlite mixes were examined using clonal plants of two cultivars, 'Stripe' and 'White Red Lip', at two-monthold and eight-month-old stages. In pots filled with $100 \% \mathrm{SM}$, water retention and total porosity were the greatest, while $\mathrm{pH}$ and $\mathrm{EC}$ were the lowest. In perlite mixes, water retention and total porosity were the lowest. The CM partially mixed with SM yielded significantly greater number of leaves, and fresh and dry weights of both cultivars at the two growth stages. Scanning electron micrographs showed no differences in the shape of stomata or transversal cells of roots among plants in pots with five different media, while leaves of granular rockwool mixes produced abundant wrinkles on their epidermis. The CM partially mixed with SM was a practical potting medium replacing SM, because of its higher potential to support the superior growth of phalaenopsis.

Key Words: coir mixes, growth, perlite, phalaenopsis, sphagnum moss.

\section{Introduction}

Phalaenopsis orchids have been grown commercially in bark, e.g., coarse fir, or redwood bark chips (Freed, 1976). Because of these orchids' succulent roots and the large size of the bark chips, potting large bare-rooted phalaenopsis plants with bark is labor intensive and increases production costs. Also, bark does not hold much water, resulting in frequent watering and slow plant recovery after being in transit for many days. Additionally, bark decomposes quickly, resulting in nutrient deficiency, poor aeration, pest infestation, and frequent repotting. Although the use of bark is rapidly increasing in Japan mainly due to the high cost of sphagnum moss, it is seldom used for phalaenopsis production, and sphagnum moss is the standard medium in Korea and Taiwan. Potting plants in other recommended media, such as sphagnum moss and shredded tree fern, requires even higher labor costs on a commercial scale. Jin and Ichihashi (2002) reported that Doritaenopsis (Dtps.) potted with New Zealand sphagnum moss grew better than when potted with New

Received; February 10, 2006. Accepted; February 2, 2007.

This work was financially supported by the Brain Korea 21 project in Korea.

* Corresponding author (E-mail: brjeong@gnu.ac.kr).
Zealand bark, coconut husk chips or rock wool. These results were due to the holding ability of moisture and mineral elements in media and mineral release from the media. It is known that water-stressed plants undergo morphological changes (Edgard et al., 2001); therefore, structural changes in plants are indicators to evaluate the media used and plant growth. To evaluate the mass production of these orchids, media with smaller particles sizes need to be developed to provide better root contact. Thus, in this study, organic and inorganic media were examined to clarify the physiological and chemical natures of potting media (coir, rockwool and perlite with known physical and chemical natures), and the growth and morphological structure of leaves and roots of phalaenopsis, to assess the possibility of substituting sphagnum moss with other easy-to-handle potting materials. For this purpose, plants at two different growth stages of two cultivars were examined.

\section{Materials and Methods}

Plant materials and media used for cultivation

Uniform, micropropagated plants of both Phalaenopsis JMP $77 \times$ Phal. Reugrih 'Stripe' (Stripe) and Dtps. City Girl M-2 $\times$ Dtps. (City Girl $\times($ Love Street $\times$ Spot Jason)) M51 'White Red Lip' (White Red Lip), purchased from a commercial propagator (Sangmi Orchid Farm Co., Taean, Korea), were selected from 
two- and eight-month-old clonal micropagules on April 27, 2002. Plants were planted in pots filled with either coir mixes (Tosilee medium, Shinan Grow Co., Korea; (CM) Coir $55 \%+$ perlite $15 \%+$ peatmoss $15 \%+$ vermiculite $10 \%+$ carbonized rice hull $5 \%), 4 \mathrm{CM}+$ 1 sphagnum moss (SM) (v/v), 2 granular rockwool (GR, Korea UR Rockwool Co., Korea) + 1 polyurethan foam (PUR, Gubaek Co., Korea) (v/v), or 1 perlite (PL, Samson Co., Korea) +1 expanded clay ball (ECB, Woojin Co., Korea) $+2 \mathrm{~cm}$ peatmoss at the bottom of the pot $(\mathrm{v} / \mathrm{v})$. New Zealand sphagnum moss (SM) was used as the control. One plant was potted in each $7.5 \mathrm{~cm}$ (two-month-old plants) or $10 \mathrm{~cm}$ (eight-month-old plants) plastic pot on June 10, 2002.

Medium water potentials of five media were monitored until they reached $-20 \mathrm{kPa}$ during 10 days with a microtensiometer (10-cm type; Daiki Co., Japan) using $7.5 \mathrm{~cm}$ pots filled with media without a plant. This process was repeated three times and the average water retention of the five media was decided as shown in Figure 1. Twenty-five pots of each medium with a plant were laid in nine tray beds (each $157 \mathrm{~cm}$ long $\times 126 \mathrm{~cm}$ wide) in a randomized complete block design with three replicates in a glasshouse covered with two layers of shade cloth to get about $30 \%$ of full sunlight. Photosynthetic photon flux (PPF) of full sunlight at the experimental location (latitude $35.15^{\circ} \mathrm{N}$ ) was about $3000 \mu \mathrm{mol} \cdot \mathrm{m}^{-2} \cdot \mathrm{s}^{-1}$ in May and $2100 \mu \mathrm{mol} \cdot \mathrm{m}^{-2} \cdot \mathrm{s}^{-1}$ in January. All plants were fertilized by an overhead irrigation method with an orchid fertilizer solution (Table 1) formulated by Ross (2001) when the water potential of each medium reached to $-20 \mathrm{kPa}$ (Fig. 1). The glasshouse was warmed by a hot water heater and was cooled by ventilation. Mean daily air temperature and $\mathrm{RH}$ during the experimental period measured by digital thermometers (Thermo Recorder TR-71S, T\&D Corp., Japan) were $25^{\circ} \mathrm{C}$ and $75 \%$, respectively. An intermittent mist system was used to increase air relative humidity.

\section{Measurements of physical properties}

To determine the physical natures of the five media, their five replicates were filled (Bilderback and Fonteno, 1987) in $7.5 \mathrm{~cm}(0.13 \mathrm{~L})$ plastic pots. Bulk density was calculated by dividing dry weight $(24 \mathrm{~h}$ at $80^{\circ} \mathrm{C}$ ) by volume (Klute, 1986). A nonlinear, fiveparameter function, developed for soils by van Genuchten and Nielsen (1985) and adapted to horticultural media by Milks et al. (1989), was used to describe the moisture retention data. The function is defined as: container capacity $(\mathrm{CC})=(($ wet weight - dry weight $) /$ volume of sample $) \times 100$, air space $(\mathrm{AS})=($ volume of water drained $/$ volume of sample $) \times 100$, and total porosity $(\mathrm{TP})=\mathrm{CC}+$ AS.

Moisture content was expressed as medium residual water after drainage by gravitation in the plastic pot. Total porosity and unavailable water were equal to the volume of water at saturation. Container capacity was predicted using the equilibrium capacity variables model

Table 1. Composition of the Ross nutrient solution used in the experiment.

\begin{tabular}{lclc}
\hline \hline \multicolumn{1}{c}{ Chemical } & $\begin{array}{c}\text { Conc. } \\
(\mathrm{g} / 100 \mathrm{~L})\end{array}$ & Chemical & $\begin{array}{c}\text { Conc. } \\
(\mathrm{g} / 100 \mathrm{~L})\end{array}$ \\
\hline $\mathrm{Ca}\left(\mathrm{NO}_{3}\right)_{2} \cdot 4 \mathrm{H}_{2} \mathrm{O}$ & 31.9 & Fe-EDTA & 1.50 \\
$\mathrm{MgSO}_{4} \cdot 7 \mathrm{H}_{2} \mathrm{O}$ & 14.8 & $\mathrm{H}_{3} \mathrm{BO}_{3}$ & 0.056 \\
$\mathrm{KNO}_{3}$ & 16.2 & $\mathrm{MnSO}_{4} \cdot 4 \mathrm{H}_{2} \mathrm{O}$ & 0.42 \\
$\mathrm{NH}_{4} \mathrm{NO}_{3}$ & 8.0 & $\mathrm{NaMoO}_{4} \cdot 2 \mathrm{H}_{2} \mathrm{O}$ & 0.002 \\
$\mathrm{KH}_{2} \mathrm{PO}_{4}$ & 13.6 & $\mathrm{ZnSO}_{4} \cdot 7 \mathrm{H}_{2} \mathrm{O}$ & 0.087 \\
$\mathrm{Mg}\left(\mathrm{NO}_{3}\right)_{2} \cdot 6 \mathrm{H}_{2} \mathrm{O}$ & 10.2 & & \\
\hline
\end{tabular}

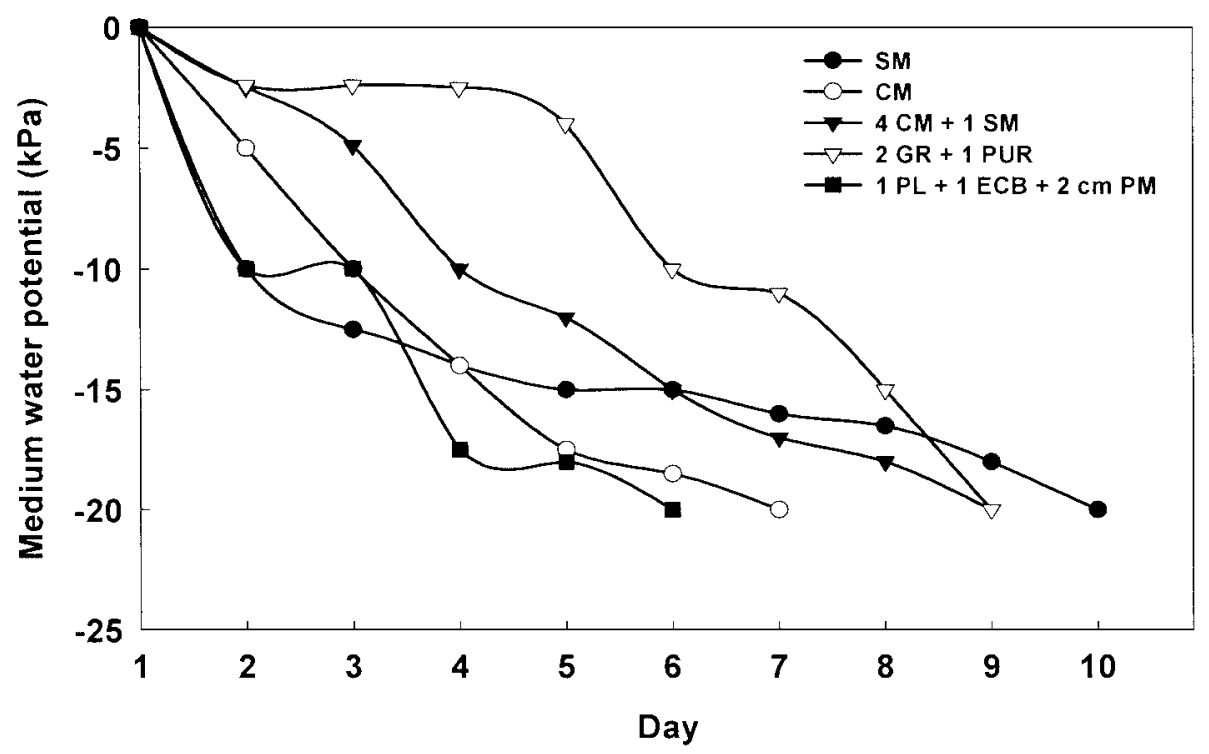

Fig. 1. Medium water retention curves of five media used in the experiment. SM, sphagnum moss; CM, coir mixes (commercial Tosilee medium); GR, granular rockwool; PUR, polyurethane foam; PL, perlite; ECB, expanded clay ball; and $2 \mathrm{~cm} \mathrm{PM,} 2 \mathrm{~cm}$ peatmoss at the bottom of the pot. 
developed by Bilderback and Fonteno (1987) and refined by Milks et al. (1989). Air space was calculated as the difference between TP and CC.

Data collected were analyzed for statistical significance by the SAS (Statistical Analysis System, V. 6.12, Cary, NC, USA) program. The experimental results were subjected to analysis of variance (ANOVA) and Tukey's multiple range tests.

\section{Measurements of $\mathrm{pH}, \mathrm{EC}$, and plant growth}

Plant growth was measured 200 days after transplanting. Growth parameters such as the number of leaves and roots, total fresh and dry weights, $\mathrm{T} / \mathrm{R}$ ratio, and $\%$ dry matter were measured. For the determination of $\mathrm{pH}$ and $\mathrm{EC}, 50 \mathrm{~mL}$ medium samples $(10 \mathrm{~cm}$ pot) from each treatment were collected at the beginning and end of the experiment, and dried for $72 \mathrm{~h}$ in a dry oven (Model FO$450 \mathrm{M}$, Jeio Technology Co. Ltd., Korea) at $60^{\circ} \mathrm{C}$. Thirty $\mathrm{mL}$ of each sample were mixed with $150 \mathrm{~mL}$ doubledistilled water and agitated for $24 \mathrm{~h}$ at $100 \mathrm{rpm}$ on a shaker (Model KS-500, KAST Scientific Instrument Co., Korea). The mixture was then filtered two times through two layers of filter paper (No. 2, Toyo Roshi Co. Ltd., Japan). About $50 \mathrm{~mL}$ solution samples were used to determine $\mathrm{pH}$ and $\mathrm{EC}$ with a $\mathrm{pH}$ (Model EA 940, Orion Research Inc., Boston, MA, USA) and an EC meter (Model C531, Consort MA, Belgium). Data were analyzed the same way as above.

\section{Morphological observation by SEM}

To investigate the effects of media on stomata and root cells, ultrastructural tissue analysis by scanning electron microscopy (SEM) was performed. The middle portion of newly developed leaves and the portion of roots $2 \mathrm{~cm}$ from their tips were collected. These samples were fixed in $3 \%(\mathrm{v} / \mathrm{v})$ glutaraldehyde overnight, then were washed three times with PBS buffer $(137 \mathrm{mM} \mathrm{NaCl}$ $\left.+2.7 \mathrm{mM} \mathrm{KCl}+43 \mathrm{mM} \mathrm{Na}_{2} \mathrm{HPO}_{4}+1.4 \mathrm{mM} \mathrm{KH}_{2} \mathrm{PO}_{4}\right)$, and finally dried with a critical point dryer (CPD2, Pelco, CA, USA). Leaf fragments and transversal sections of roots were positioned on stubs prior to gold coating in a sputter coater (SC 7640, Polaron, Sussex, England). A sputtering current of $20 \mathrm{~mA}$ was applied for $4 \mathrm{~min}$, giving a gold coating with a thickness of approximately $10 \mathrm{~nm}$. Specimens were then observed and photographed by SEM (LEO-435VP, Zesis, Germany). The epidermis including stomata in leaves and transversal cell shapes of roots were mainly observed.

\section{Results and discussion}

\section{Physical properties of potted media}

The physical properties of the media filling the $7.5 \mathrm{~cm}$ $(0.13 \mathrm{~L})$ pots differed significantly (Table 2$)$. Total porosity was the highest (94\%) in SM, followed by 2 GR +1 PUR, $100 \% \mathrm{CM}$ and $4 \mathrm{CM}+1 \mathrm{SM}$, and was the lowest (77\%) in $1 \mathrm{PL}+1 \mathrm{ECB}+2 \mathrm{~cm}$ PM. Container capacity was the highest (77\%) in SM and the lowest $(51 \%)$ in $1 \mathrm{PL}+1 \mathrm{ECB}+2 \mathrm{~cm}$ PM. These results were similar to those obtained by Wang (1995b) who showed that the total porosity of sphagnum moss was greater than that of bark. The moisture content of SM was the highest (86\%), followed by $2 \mathrm{GR}+1 \mathrm{PUR}, 4 \mathrm{CM}+1 \mathrm{SM}, 100 \%$ $\mathrm{CM}$, and $1 \mathrm{PL}+1 \mathrm{ECB}+2 \mathrm{~cm} \mathrm{PM}$. Air space ranged from 11 to $26 \%$ and was the highest $(26 \%)$ in $1 \mathrm{PL}+1 \mathrm{ECB}$ $+2 \mathrm{~cm}$ PM and the lowest (11\%) in 100\% CM and 2 GR +1 PUR. According to reports reviewed by Heiskanen (1993), adequate substrate aeration is of critical importance for plants grown in containers. It can be achieved by holding the air space of container substrates to at least $10 \%$ of their total volumes (Bugbee and Frink, 1986). Also, according to Kramer (1983), the usual concentration of $\mathrm{O}_{2}$ in media can be low enough to harm plants, but the $\mathrm{CO}_{2}$ level is generally not high enough to be injurious. In this experiment, air space was greater than $10 \%$ in all media tested.

Bulk density ranged from 116 of SM to $158 \mathrm{~kg} \cdot \mathrm{m}^{-3}$ of $1 \mathrm{PL}+1 \mathrm{ECB}+2 \mathrm{~cm}$ PM. The trend that inorganic substrates show high bulk densities appears in the recommendations by Boodley and Sheldrake (1982) and Nelson (1998). Nearly all solid substrates will provide anchorage for plant roots, but it is also important that the substrate be sufficiently heavy to prevent the plant pot from falling over. A mixture of equal parts of sphagnum peat moss and perlite is sufficiently heavy just after watering, but when the available water has been used, large plants easily topple over when handled.

Table 2. Physical properties of the five media used in the experiment.

\begin{tabular}{lccccc}
\hline \hline \multicolumn{1}{c}{ Medium $^{z}$} & T.P. $(\%)$ & C.C. $(\%)$ & M.C. $(\%)$ & A.S. $(\%)$ & B.D. $\left(\mathrm{kg} \cdot \mathrm{m}^{-3}\right)$ \\
\hline $\mathrm{SM}$ & $94 \mathrm{a}^{\mathrm{x}}$ & $77 \mathrm{a}$ & $86 \mathrm{a}$ & $17 \mathrm{~b}$ & $116 \mathrm{c}$ \\
$\mathrm{CM}$ & $78 \mathrm{c}$ & $67 \mathrm{c}$ & $54 \mathrm{~b}$ & $11 \mathrm{c}$ & $133 \mathrm{~b}$ \\
$4 \mathrm{CM}+1 \mathrm{SM}$ & $78 \mathrm{c}$ & $63 \mathrm{c}$ & $56 \mathrm{~b}$ & $15 \mathrm{~b}$ & $132 \mathrm{~b}$ \\
$2 \mathrm{GR}+1 \mathrm{PUR}$ & $83 \mathrm{~b}$ & $72 \mathrm{~b}$ & $58 \mathrm{~b}$ & $11 \mathrm{c}$ & $135 \mathrm{~b}$ \\
$1 \mathrm{PL}+1 \mathrm{ECB}+2 \mathrm{~cm} \mathrm{PM}$ & $77 \mathrm{c}$ & $51 \mathrm{~d}$ & $47 \mathrm{c}$ & $26 \mathrm{a}$ & $158 \mathrm{a}$ \\
\hline
\end{tabular}

z SM, sphagnum moss (New Zealand); CM, coir mixes (commercial Tosilee medium); GR, granular rockwool; PUR, polyurethane foam; PL, perlite; ECB, expanded clay ball; and $2 \mathrm{~cm} \mathrm{PM,} 2 \mathrm{~cm}$ peatmoss at the bottom of the pot.

y T.P., total porosity; C.C., container capacity; M.C., moisture content; A.S., air space; and B.D., bulk density.

${ }^{x}$ Mean separation within columns by Tukey's multiple range test at $P \leq 0.05$. 
On the other hand, a high bulk density is uneconomical because of the extra labor of handling such a substrate. Thus, in this experiment, all media had bulk densities suggested by Nelson (1998).

The water retention time to reach to $-20 \mathrm{kPa}$ was 6 , $7,9,9$, and 10 days for $1 \mathrm{PL}+1 \mathrm{ECB}+2 \mathrm{~cm} \mathrm{PM}, 100 \%$ $\mathrm{CM}, 4 \mathrm{CM}+1 \mathrm{SM}, 2 \mathrm{GR}+1 \mathrm{PUR}$, and $100 \% \mathrm{SM}$, respectively (Fig. 1). This pattern that organic substrates have higher retention times resembles the results that the water-holding capacity of perlite and the clay ball was lower than that of sphagnum moss and peatmoss (Bunt, 1988; Ross, 2001; van Iersel, 1999). The water retention curve in $4 \mathrm{CM}+1 \mathrm{SM}$ decreased linearly and more slowly than in the other media, except $2 \mathrm{GR}+$ 1 PUR, which held the water potential at higher levels over time. This was especially obvious for the first five days, but after five days, it decreased drastically. On the other hand, SM medium lost a great deal of medium water potential in the first three days and held the remaining water well until 10 days. $100 \% \mathrm{CM}$ and $1 \mathrm{PL}$ $+1 \mathrm{ECB}+2 \mathrm{~cm}$ PM medium lost medium water very quickly and reached $-20 \mathrm{kPa}$ water potential in 7 and 6 days, respectively.

\section{pH and EC of media before and after culture and plant growth}

The initial pHs of the media were in the range of 5.11 to 7.65 , while the $\mathrm{pH}$ of all media, except $2 \mathrm{GR}+1$ PUR and $1 \mathrm{PL}+1 \mathrm{ECB}+2 \mathrm{~cm} \mathrm{PM}$, dropped after 200 days of culture. The initial and final $\mathrm{pHs}$ of the control $(100 \%$ SM) were the lowest, being 5.11 and 4.90, respectively, in the 'Stripe' cultivar. Also, those of $2 \mathrm{GR}+1$ PUR treatment were the highest, 7.20 and 7.65 , respectively, in the 'Stripe' cultivar (Table 3). This was due to the alkaline nature of granular rockwool and polyurethane foam. Nelson (1998) suggested that the optimum $\mathrm{pH}$ of the artificial medium with good availability of all essential elements is between 5.6 and 6.2. Helton (1969) reported that three epiphytic orchids, including phalaenopsis, grew best in a medium with a $\mathrm{pH}$ ranging between 4.5 and 5.5, possibly due to increased levels of soluble micronutrients. Although the $\mathrm{pH}$ in some media in this experiment was higher than this optimum range, no elemental deficiency or toxicity symptoms were observed.

The initial EC of the media was in the range from 99 to $218 \mu \mathrm{S} \cdot \mathrm{cm}^{-1}$. These values were obtained from the diluted sample ( $30 \mathrm{~mL}$ medium to $150 \mathrm{~mL} \mathrm{H}_{2} \mathrm{O}$ dilution). Initial EC in SM medium was the lowest and was similar between cultivars. As expected, it increased in all plots during the experiment, but the increase was smallest in the control (SM) and the greatest in coir mixes (CM). Those rises are naturally caused by salt accumulation in the media, because fertilization was repeated through culture. Moreover, $\mathrm{CM}$ has the potential to retain minerals much more than SM because it includes peatmoss, which has a high ion exchange capacity. These results are similar to those by Shinohara et al. (1999) who reported that the EC values of organic substrate were slightly higher than those of inorganic substrates. Wang (1995a) suggested that an EC as high as $1100 \mu \mathrm{S} \cdot \mathrm{cm}^{-1}$ produced good phalaenopsis plants with large leaves. In this experiment, the EC value of all treatments fell in this range in both cultivars.

The growth characteristics of two-month-old plants of both 'Stripe' and 'White Red Lip' cultivars, harvested at 200 days after transplanting, are shown in Table 4. Both cultivars showed significantly greater numbers of leaves at $100 \% \mathrm{CM}$ and $4 \mathrm{CM}+1 \mathrm{SM}$ than the control. The numbers of roots of both cultivars in those media

Table 3. The $\mathrm{pH}$ and EC of the growing media before and after 200 days of culture of phalaenopsis in the greenhouse.

\begin{tabular}{|c|c|c|c|c|}
\hline \multirow{2}{*}{ Medium $^{\mathrm{x}}$} & \multicolumn{2}{|c|}{$\mathrm{p \textrm {pH }}$} & \multicolumn{2}{|c|}{$\overline{E C C}\left(\mu \mathrm{S} \cdot \mathrm{cm}^{-1}\right)^{y}$} \\
\hline & Before & After & Before & After \\
\hline \multicolumn{5}{|l|}{ 'Stripe' cultivar } \\
\hline SM & $5.11 \mathrm{~b}^{\mathrm{z}}$ & $4.90 \mathrm{~d}$ & $99 \mathrm{c}$ & $523 \mathrm{c}$ \\
\hline $\mathrm{CM}$ & $6.16 \mathrm{ab}$ & $5.36 \mathrm{c}$ & $218 \mathrm{a}$ & $975 \mathrm{a}$ \\
\hline $4 \mathrm{CM}+1 \mathrm{SM}$ & $6.19 \mathrm{ab}$ & $5.31 \mathrm{c}$ & $157 \mathrm{ab}$ & $846 \mathrm{~b}$ \\
\hline $2 \mathrm{GR}+1 \mathrm{PUR}$ & $7.20 \mathrm{a}$ & $7.65 \mathrm{a}$ & $129 \mathrm{~b}$ & $809 \mathrm{~b}$ \\
\hline $1 \mathrm{PL}+1 \mathrm{ECB}+2 \mathrm{~cm} \mathrm{PM}$ & $6.11 \mathrm{ab}$ & $6.57 \mathrm{~b}$ & $111 \mathrm{~b}$ & $880 \mathrm{~b}$ \\
\hline \multicolumn{5}{|l|}{ 'White Red Lip' cultivar } \\
\hline SM & $5.11 \mathrm{~b}$ & $4.80 \mathrm{~d}$ & $99 \mathrm{c}$ & $671 \mathrm{c}$ \\
\hline $\mathrm{CM}$ & $6.16 \mathrm{ab}$ & $5.59 \mathrm{c}$ & $218 \mathrm{a}$ & $900 \mathrm{a}$ \\
\hline $4 \mathrm{CM}+1 \mathrm{SM}$ & $6.19 \mathrm{ab}$ & $5.00 \mathrm{c}$ & $157 \mathrm{ab}$ & $786 \mathrm{~b}$ \\
\hline $2 \mathrm{GR}+1 \mathrm{PUR}$ & $7.20 \mathrm{a}$ & $7.50 \mathrm{a}$ & $129 \mathrm{~b}$ & $723 \mathrm{~b}$ \\
\hline $1 \mathrm{PL}+1 \mathrm{ECB}+2 \mathrm{~cm} \mathrm{PM}$ & $6.11 \mathrm{ab}$ & $6.35 \mathrm{~b}$ & $111 \mathrm{~b}$ & $688 \mathrm{c}$ \\
\hline
\end{tabular}

x SM, sphagnum moss (New Zealand); CM, coir mixes (commercial Tosilee medium); GR, granular rockwool; PUR, polyurethane foam; PL, perlite; ECB, expanded clay ball; and $2 \mathrm{~cm} \mathrm{PM,} 2 \mathrm{~cm}$ peatmoss at the bottom of the pot.

y Solutions of 1 medium to $5 \mathrm{H}_{2} \mathrm{O}(\mathrm{v} / \mathrm{v})$ dilutions.

${ }^{z}$ Mean separation within columns by Tukey's multiple range test at $P \leq 0.05$. 
Table 4. Effect of the five media on the growth of two months old phalaenopsis plants harvested at 200 days after transplanting.

\begin{tabular}{|c|c|c|c|c|c|c|}
\hline \multirow{2}{*}{ Medium $^{2}$} & \multicolumn{2}{|c|}{ Number of } & \multirow{2}{*}{$\begin{array}{l}\text { Total fresh } \\
\text { weight }(\mathrm{g})\end{array}$} & \multirow{2}{*}{$\begin{array}{c}\text { Total dry } \\
\text { weight }(\mathrm{g})\end{array}$} & \multirow{2}{*}{$\mathrm{T} / \mathrm{R}$ ratio } & \multirow{2}{*}{ Dry matter $(\%)$} \\
\hline & Leaves & roots & & & & \\
\hline \multicolumn{7}{|l|}{ 'Stripe' cultivar } \\
\hline SM & $3.3 \mathrm{~b}^{\mathrm{y}}$ & $11.3 \mathrm{a}$ & $26.8 \mathrm{~b}$ & $2.5 \mathrm{ab}$ & $2.3 \mathrm{a}$ & $9.3 \mathrm{a}$ \\
\hline $\mathrm{CM}$ & $3.7 \mathrm{a}$ & $7.0 \mathrm{c}$ & $32.9 \mathrm{ab}$ & $2.2 \mathrm{~b}$ & $2.4 \mathrm{a}$ & $6.7 \mathrm{~b}$ \\
\hline $4 \mathrm{CM}+1 \mathrm{SM}$ & $3.7 \mathrm{a}$ & $5.0 \mathrm{~d}$ & $39.4 \mathrm{a}$ & $2.7 \mathrm{a}$ & $2.6 \mathrm{a}$ & $6.8 \mathrm{~b}$ \\
\hline $2 \mathrm{GR}+1 \mathrm{PUR}$ & $3.0 \mathrm{~b}$ & $10.3 \mathrm{ab}$ & $36.5 \mathrm{ab}$ & $2.5 \mathrm{ab}$ & $2.5 \mathrm{a}$ & $6.8 \mathrm{~b}$ \\
\hline $1 \mathrm{PL}+1 \mathrm{ECB}+2 \mathrm{~cm} \mathrm{PM}$ & $3.3 \mathrm{~b}$ & $8.0 \mathrm{~b}$ & $38.6 \mathrm{a}$ & $2.5 \mathrm{ab}$ & $1.8 \mathrm{~b}$ & $6.5 \mathrm{~b}$ \\
\hline \multicolumn{7}{|l|}{ 'White Red Lip' cultivar } \\
\hline SM & $3.0 \mathrm{~b}$ & $9.7 \mathrm{a}$ & $25.7 \mathrm{c}$ & $1.5 \mathrm{bc}$ & $2.9 \mathrm{~b}$ & $5.8 \mathrm{a}$ \\
\hline $\mathrm{CM}$ & $4.3 \mathrm{a}$ & $4.0 \mathrm{c}$ & $30.3 \mathrm{~b}$ & $1.6 \mathrm{bc}$ & $3.9 \mathrm{a}$ & $5.3 \mathrm{~b}$ \\
\hline $4 \mathrm{CM}+1 \mathrm{SM}$ & $4.3 \mathrm{a}$ & $4.0 \mathrm{c}$ & $72.1 \mathrm{a}$ & $4.0 \mathrm{a}$ & $4.3 \mathrm{a}$ & $5.5 \mathrm{~b}$ \\
\hline $2 \mathrm{GR}+1 \mathrm{PUR}$ & $4.0 \mathrm{ab}$ & $5.0 \mathrm{~b}$ & $38.7 \mathrm{~b}$ & $2.2 \mathrm{~b}$ & $2.7 \mathrm{~b}$ & $5.7 \mathrm{a}$ \\
\hline $1 \mathrm{PL}+1 \mathrm{ECB}+2 \mathrm{~cm} \mathrm{PM}$ & $4.0 \mathrm{ab}$ & $9.3 \mathrm{a}$ & $33.3 \mathrm{~b}$ & $2.0 \mathrm{~b}$ & $2.3 \mathrm{~b}$ & $6.0 \mathrm{a}$ \\
\hline
\end{tabular}

${ }^{\text {z }}$ SM, sphagnum moss (New Zealand); CM, coir mixes (commercial Tosilee medium); GR, granular rockwool; PUR, polyurethane foam; PL, perlite; ECB, expanded clay ball; and $2 \mathrm{~cm} \mathrm{PM,} 2 \mathrm{~cm}$ peatmoss at the bottom of the pot.

${ }^{y}$ Mean separation within columns by Tukey's multiple range test at $P \leq 0.05$.

Table 5. Effect of the five media on the growth of eight months old phalaenopsis plants harvested at 200 days after transplanting.

\begin{tabular}{|c|c|c|c|c|c|c|}
\hline \multirow{2}{*}{ Medium $^{z}$} & \multicolumn{2}{|c|}{ Number of } & \multirow{2}{*}{$\begin{array}{l}\text { Total fresh } \\
\text { weight }(\mathrm{g})\end{array}$} & \multirow{2}{*}{$\begin{array}{c}\text { Total dry } \\
\text { weight }(\mathrm{g})\end{array}$} & \multirow{2}{*}{$\mathrm{T} / \mathrm{R}$ ratio } & \multirow{2}{*}{ Dry matter $(\%)$} \\
\hline & leaves & roots & & & & \\
\hline \multicolumn{7}{|l|}{ 'Stripe' cultivar } \\
\hline SM & $4.3 \mathrm{ab}^{\mathrm{y}}$ & $15 \mathrm{a}$ & $133.3 \mathrm{a}$ & $8.6 \mathrm{ab}$ & $2.6 \mathrm{ab}$ & $6.5 \mathrm{~b}$ \\
\hline $\mathrm{CM}$ & $4.3 \mathrm{ab}$ & $13 \mathrm{a}$ & $119.0 \mathrm{ab}$ & $8.0 \mathrm{ab}$ & $2.6 \mathrm{ab}$ & $6.7 \mathrm{~b}$ \\
\hline $4 \mathrm{CM}+1 \mathrm{SM}$ & $5.0 \mathrm{a}$ & $15 \mathrm{a}$ & $133.6 \mathrm{a}$ & $9.0 \mathrm{a}$ & $2.8 \mathrm{a}$ & $6.7 \mathrm{~b}$ \\
\hline $2 \mathrm{GR}+1 \mathrm{PUR}$ & $3.3 \mathrm{~b}$ & $14 \mathrm{a}$ & $99.9 \mathrm{~b}$ & $7.8 \mathrm{~b}$ & $2.2 \mathrm{~b}$ & $7.8 \mathrm{ab}$ \\
\hline $1 \mathrm{PL}+1 \mathrm{ECB}+2 \mathrm{~cm} \mathrm{PM}$ & $3.7 \mathrm{~b}$ & $14 \mathrm{a}$ & $80.0 \mathrm{c}$ & $6.9 \mathrm{c}$ & $1.7 \mathrm{c}$ & $8.7 \mathrm{a}$ \\
\hline \multicolumn{7}{|l|}{ 'White Red Lip' cultivar } \\
\hline SM & $5.7 \mathrm{ab}$ & $13 \mathrm{a}$ & $111.4 \mathrm{~b}$ & $6.5 \mathrm{~b}$ & $2.9 \mathrm{ab}$ & $5.9 \mathrm{ab}$ \\
\hline $\mathrm{CM}$ & $5.7 \mathrm{ab}$ & $12 \mathrm{a}$ & $114.3 \mathrm{~b}$ & $8.0 \mathrm{ab}$ & $3.1 \mathrm{ab}$ & $6.9 \mathrm{a}$ \\
\hline $4 \mathrm{CM}+1 \mathrm{SM}$ & $6.7 \mathrm{a}$ & $16 \mathrm{a}$ & $173.1 \mathrm{a}$ & $9.5 \mathrm{a}$ & $3.7 \mathrm{a}$ & $5.5 \mathrm{~b}$ \\
\hline $2 \mathrm{GR}+1 \mathrm{PUR}$ & $5.3 \mathrm{~b}$ & $14 \mathrm{a}$ & $105.9 \mathrm{~b}$ & $6.7 \mathrm{~b}$ & $3.0 \mathrm{ab}$ & $6.3 \mathrm{a}$ \\
\hline $1 \mathrm{PL}+1 \mathrm{ECB}+2 \mathrm{~cm} \mathrm{PM}$ & $5.3 \mathrm{~b}$ & $13 \mathrm{a}$ & $117.4 \mathrm{~b}$ & $7.7 \mathrm{ab}$ & $1.9 \mathrm{~b}$ & $6.5 \mathrm{a}$ \\
\hline
\end{tabular}

${ }^{z}$ SM, sphagnum moss (New Zealand); CM, coir mixes (commercial Tosilee medium); GR, granular rockwool; PUR, polyurethane foam; PL, perlite; ECB, expanded clay ball; and $2 \mathrm{~cm}$ PM, $2 \mathrm{~cm}$ peatmoss at the bottom of the pot.

${ }^{y}$ Mean separation within columns by Tukey's multiple range test at $P \leq 0.05$.

were significantly lower than the control $(100 \% \mathrm{SM})$; however, $4 \mathrm{CM}+1 \mathrm{SM}$ medium increased root mass rather than the numbers of roots in both cultivars (data not shown). The greatest total fresh and dry weights were obtained in the $4 \mathrm{CM}+1 \mathrm{SM}$ treatment in 'White Red Lip' (Table 4). Also, in the same medium, the highest values of the $\mathrm{T} / \mathrm{R}$ ratio appeared in both cultivars. This is believed to be due in part to the maintenance of adequate water-holding capacity (Fig. 1) (Konow, 1998), adequate $\mathrm{pH}$ levels and nutritional status (Table 3 ).

Table 5 shows the growth of eight-month-old plants harvested at 200 days after planting. Growth characteristics of both cultivars were similar to those of twomonth-old plants. Although the number of leaves was greater in 'White Red Lip' than 'Stripe', it was the greatest in $4 \mathrm{CM}+1 \mathrm{SM}$ in both cultivars, whereas those of $2 \mathrm{GR}+1 \mathrm{PUR}$ and $1 \mathrm{PL}+1 \mathrm{ECB}+2 \mathrm{~cm}$ PM were significantly lower than in other media. Although the number of roots was not affected by medium treatment in both cultivars, the $4 \mathrm{CM}+1 \mathrm{SM}$ medium presented the highest total fresh and dry weights and T/R ratio; those values were significantly different from the lowest values in other media. Wang and Gregg (1994) reported that phalaenopsis plants grown in a bark-peat medium were much larger than those grown in bark. The addition of sphagnum peat to fir bark chips promoted plant growth, regardless of the fertilizer used. This resulted from the greater water-holding capacity of the bark-peat medium than the bark medium (Konow, 1998). Also, the promoted growth of two cultivars in the $4 \mathrm{CM}+1 \mathrm{SM}$ medium indicates that this medium provided a higher cation exchange capacity than sphagnum moss alone, due to the property of peat moss mixed in. 


\section{Morphological changes in leaves and roots}

The SEM micrographs of leaves in 'Stripe' cultivar sampled from the five media are shown in Fig. 2. Stomata of leaves in four medium treatments except the $2 \mathrm{GR}+1$ PUR treatment displayed the normal morphology. The lower epidermis of leaves in the $2 \mathrm{GR}+1$ PUR (Fig. 2D) had abundant wrinkles. This observation seems to be related to the yielded excessive water condition and $\mathrm{O}_{2}$ shortage caused by the medium in the $2 \mathrm{GR}+$ 1 PUR treatment. Water-stressed plants are known to have a reduced number of palisade cell layers, irregular epidermal tissue, large intercellular spaces in the mesophyll, reduced lignification, tin cell walls, reduced vascular tissue, and the presence of a thin cuticle or no cuticle at all (Edgard et al., 2001). When planted in 2 GR +1 PUR, roots usually do not have tight contact with the loose, porous medium particles as they do with water in a solution culture. Phalaenopsis orchids have relatively few roots, making them unable to explore a large volume of the medium (Wang and Gregg, 1994). Also, the porous media probably did not retain a sufficient amount of nutrients for optimum plant growth because of lower fertility levels (Poole and Seeley, 1977); therefore, a higher container capacity and moisture content are needed for better plant performance in medium culture (Lee and Lin, 1987).

The SEM micrographs of the transversal section of a root sampled from the five media of 'Stripe' cultivar indicate xylem, endodermis, phloem, cortex, exodermises, and velamen (Fig. 3). In $4 \mathrm{CM}+1 \mathrm{SM}$ and $1 \mathrm{PL}$ $+1 \mathrm{ECB}+2 \mathrm{~cm}$ PM medium treatments slightly expanded cortical cells were observed. Transversal cell shapes of tissues mentioned above were not affected by the medium composition.

The findings that plants of two cultivars at two growth stages had a greater number of leaves, and fresh and dry weights when potted in $4 \mathrm{CM}+1 \mathrm{SM}$ than in other media, including $100 \%$ New Zealand sphagnum moss, means
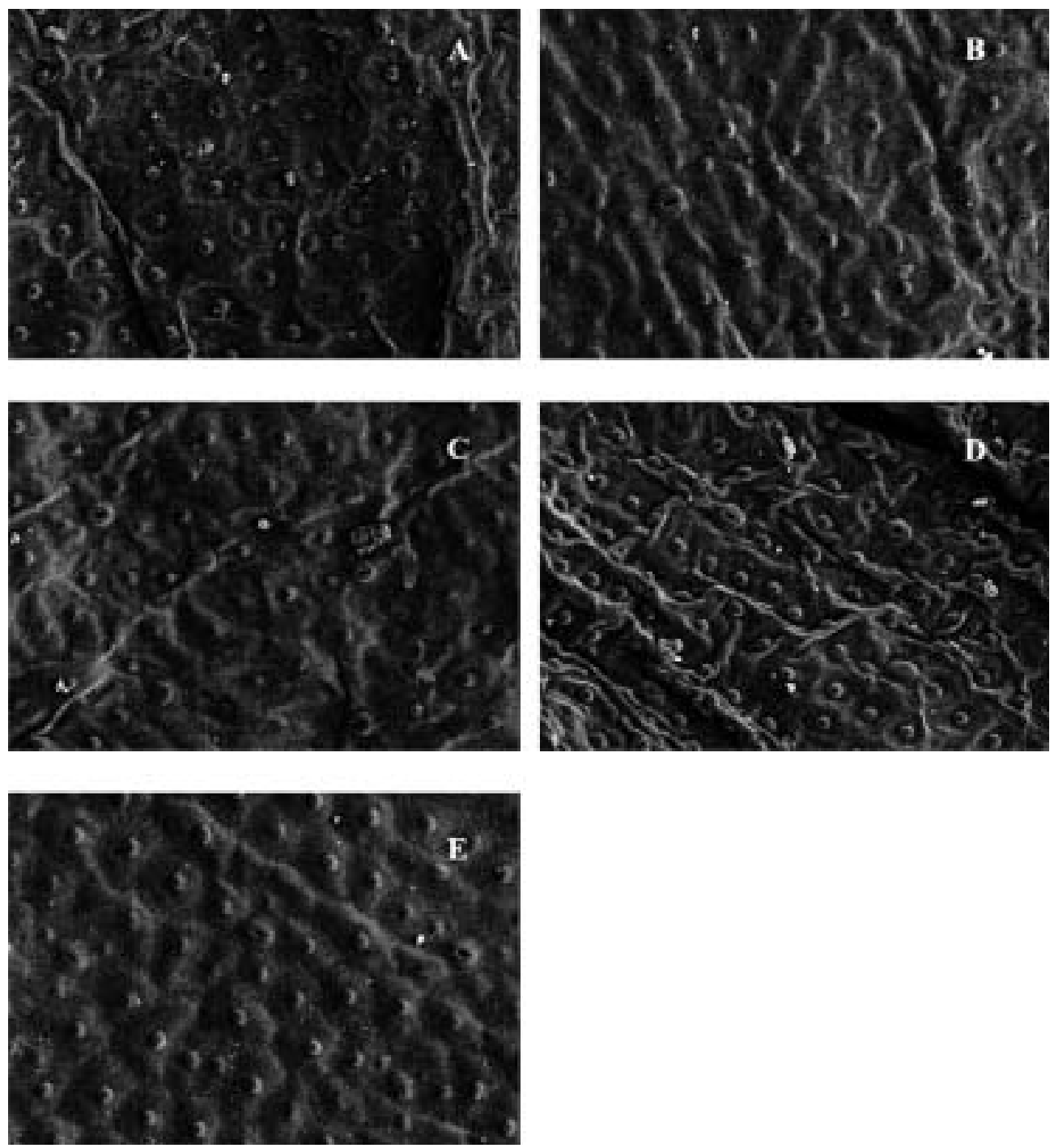

Fig. 2. Scanning electron micrographs of leaf stomata and papilla of 'Stripe' plants grown in different media for 200 days. A, sphagnum moss (SM); B, coir mixes (CM); C, 4 CM + 1 SM; D, 2 granular rockwool (GR) + 1 polyurethane foam (PUR); and E, 1 perlite (PL) + 1 expanded clay ball $(\mathrm{ECB})+2 \mathrm{~cm}$ peatmoss at the bottom of the pot $(2 \mathrm{~cm} \mathrm{PM})$. 

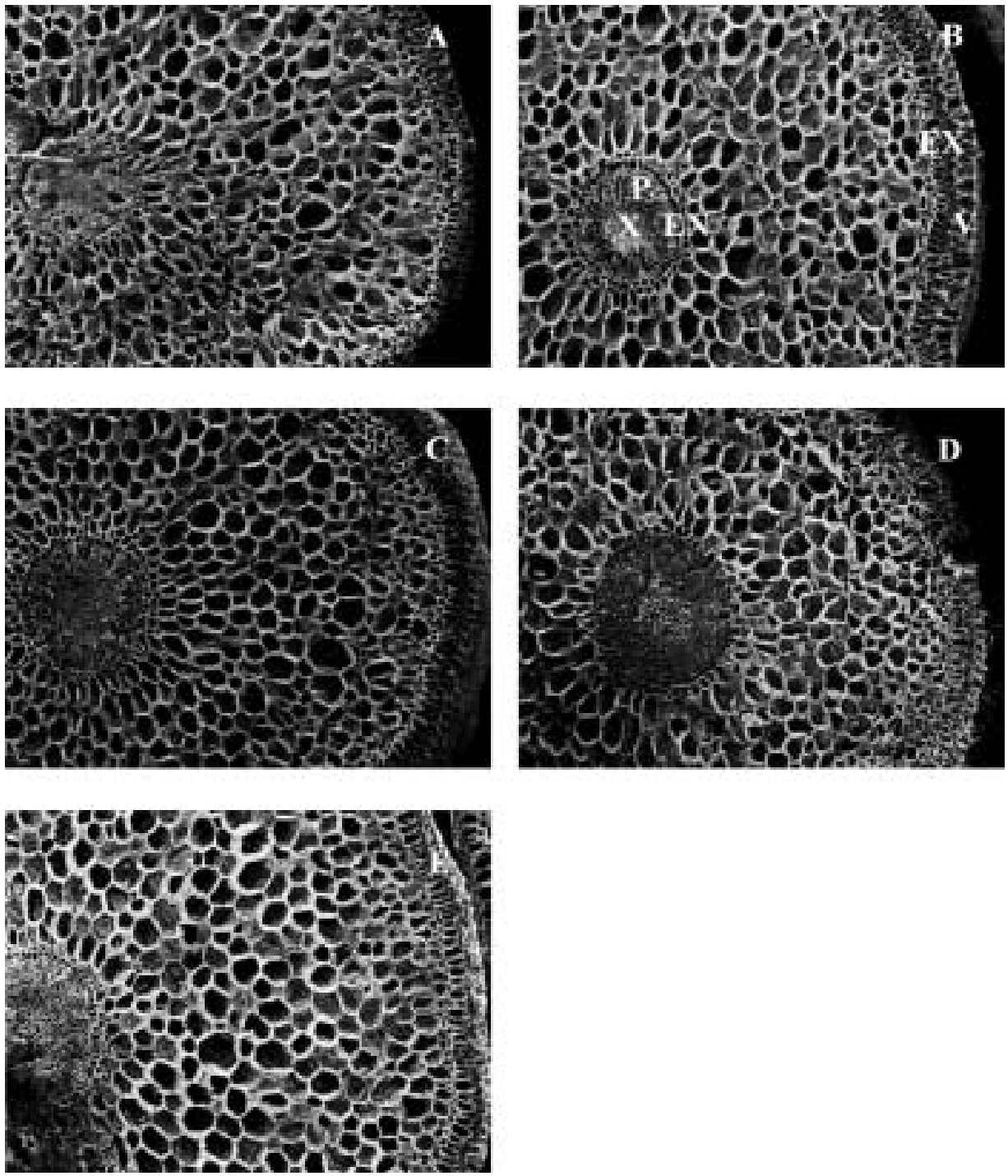

Fig. 3. Scanning electron micrographs of a transversal section of a root of 'Stripe' cultivar grown in different media. A, SM; B, CM; C, 4 CM +1 SM; D, 2 GR + 1 PUR; and E, 1 PL+1 ECB + 2 cm PM. X, xylem; EN, endodermis; P, phloem; C, cortex; EX, exodermis; and V, velamen.

the availability of this medium as a practical potting medium to replace sphagnum moss. Sphagnum moss, when mixed with commercial horticultural medium composed of coir, has been found to increase the retention of moisture and nutrients. Coir mixes also provided the same air space of pots and improved bulk density as sphagnum moss. The cultivation of potted phalaenopsis orchids in $4 \mathrm{CM}+1 \mathrm{SM}$ rather than $100 \%$ New Zealand sphagnum moss is expected to save a significant amount of labor for potting and overall production costs. The best medium for the growth of potted phalaenopsis production was $4 \mathrm{CM}+1 \mathrm{SM}$ in this experiment.

\section{Literature Cited}

Bilderback, T. E. and W. C. Fonteno. 1987. Effects of container geometry and media physical properties on the air and water volumes in containers. J. Environ. Hort. 5: 180-182.

Boodley, J. W. and R. Sheldrake Jr. 1982. Cornell peat-lite mixes for commercial plant growing. New York State College Agr. Life Sci. Ext. Info. Bull. 43.

Bugbee, G. J. and C. R. Frink. 1986. Aeration of potting media and plant growth. Soil Sci. 141: 438-441.

Bunt, A. C. 1988. A manual on the preparation and use of growing media for pot plants. p. 79-83. In: A. C. Bunt (ed.). Media and mixes for container grown plants. Unwin Hyman, London.

Edgard, A. T. P., C. O. Wagner, L. F. Maira, M. B. C. Sonia, S. A. Raul, A. M. S. Dldo, R. C. Carlos and P. B. F. Elizabeth. 2001. Hyperhydricity in in vitro eggplant regenerated plants: Structural characteristics and involvement of BiP (Binding Protein). Plant Sci. 160: 857-868.

Freed, H. 1976. Phalaenopsis are easy to grow. Amer. Orchid Soc. Bull. 45: 405-408.

Heiskanen, J. 1993. Favorable water and aeration conditions for growth media used in containerized tree seedling production: A review. Scand. J. For. Res. 8: 337-358.

Helton, O. M. 1969. Growing orchids under controlled $\mathrm{pH}$ conditions. Amer. Orchid Soc. Bull. 38: 126-129.

Jin, X. and S. Ichihashi. 2002. Ion release from potting materials, 
the absorption of ions from nutrient solution and growth of Doritaenosis. J. Japan. Soc. Hort. Sci. 71: 434-440.

Klute, A. 1986. Water retention: Laboratory methods. p. 635-662. In: A. Klute (ed.). Methods of soil analysis, Part 1. Physical and mineralogical methods. Monogrph. 9. Amer. Soc. Agron., Madison.

Konow, E. A. 1998. The effects of in vitro and greenhouse irradiance, fertility, and media on the growth of a hybrid phalaenopsis orchid. MS Thesis. Texas A\&M Univ., College Station.

Kramer, P. J. 1983. Water relations of plants. p. 146-186. In: P. J. Kramer (ed.). Development of root systems. Academic Press, New York.

Lee, N. and G. M. Lin. 1987. Controlling the flowering of phalaenopsis. p. 27-44. In: L. R. Chang (ed.). Proc. Symp. Forcing Culture Hort. Crops. Special Publ. 10. Taichung District Agr. Improv. Sta., Taiwan.

Milks, R. R., W. C. Fonteno and R. A. Larson. 1989. Hydrology of horticultural substrates. II. Predicting physical properties of substrate in containers. J. Amer. Soc. Hort. Sci. 114: 53-56.

Nelson, P. V. 1998. Greenhouse operation and management. 5th ed. Prentice Hall, Upper Saddle River.

Poole, H. A. and J. G. Seeley. 1977. Effect of artificial light sources, intensity, watering frequency and fertilization practice on growth of Cattleya, Cymbidium and Phalaenopsis orchids.
Amer. Orchid Soc. Bull. 46: 923-928.

Ross, J. 2001. The world of orchids. p. 148-159. In: J. Ross (ed.). A practical guide to cultivating orchids in soilless culture. Casper Publication, Narrabeen.

Shinohara, Y., T. Hata, T. Maru, M. Hohjo and T. Ito. 1999. Chemical and physical properties of the coconut-fiber substrate and the growth and productivity of tomato (Lycopersicum escullentum Mill.) plants. Acta Hort. 481: 145-149.

van Genuchten, M. T. and D. R. Nielson. 1985. On describing and predicting the hydraulic properties of unsaturated soils. E. G. S. Ann. Geophysicae 3: 615-628.

van Iersel, M. 1999. Fertilizer concentration affects growth and nutrient composition of subirrigated pansies. HortScience 34: 660-663.

Wang, Y. T. 1995a. Impact of salinity and media on growth and flowering of a hybrid phalaenopsis orchid. HortScience 33: 247-250.

Wang, Y. T. 1995b. Medium and fertilization affect performance of potted Dendrobium and Phalaenopsis. HortTechnology 5: 234-237.

Wang, Y. T. and L. L. Gregg. 1994. Medium and fertilizer affect the performance of phalaenopsis orchids during two flowering cycles. HortScience 29: 269-271. 